\title{
Identificação e caracterização de genes vip e cry coleóptero-específicos em isolados de Bacillus thuringiensis
}

\author{
Meire de Cássia Alves ${ }^{(1)}$, Juliana Regina Rossi ${ }^{(1)}$, Maria Gabriela Fontanetti Rodrigues ${ }^{(2)}$, \\ Eliane Cristina da Cunha Alves ${ }^{(1)}$, Antonio Sergio Ferraudo(1), Manoel Victor Franco Lemos ${ }^{(1)}$, \\ Janete Apparecida Desidério(1) e Odair Aparecido Fernandes ${ }^{(1)}$
}

\begin{abstract}
(1)Universidade Estadual Paulista, Faculdade de Ciências Agrárias e Veterinárias, Via de Acesso Prof. Paulo Donato Castellane, s/no, CEP 14884-900 Jaboticabal, SP. E-mail: meirebiosg@yahoo.com.br, jurossi@fcav.unesp.br, elianea@fcav.unesp.br, fsajago@gmail.com, mvictor@fcav.unesp.br, janete@fcav.unesp.br, oafernandes@fcav.unesp.br (2)Universidade de São Paulo, Avenida Bandeirantes, no 3.900, Monte Alegre, CEP 14040-900 Ribeirão Preto, SP. E-mail: gabrielafontanetti@hotmail.com
\end{abstract}

Resumo - O objetivo deste trabalho foi identificar e caracterizar os genes cry3, vip1, vip2 e vip1/vip2 em uma coleção de 1.078 isolados de Bacillus thuringiensis potencialmente tóxicos para larvas de coleópteros. Foram utilizados pares de oligonucleotídeos iniciadores gerais obtidos a partir de regiões conservadas dos genes e do alinhamento de sequências consenso. Posteriormente, os isolados positivos foram caracterizados por meio da técnica de PCR-RFLP, tendo-se utilizado enzimas de restrição específicas, para identificar novas subclasses de genes nos isolados. Cento e cinquenta e um isolados foram positivos para os genes avaliados, com maior frequência para o gene vip1/vip2 (139 isolados). Pela técnica de PCR-RFLP, foram observados 14 perfis polimórficos, o que indica a presença de diferentes alelos e, consequentemente, de distintas subclasses desses genes.

Termos para indexação: bioprospecção, Coleoptera, controle biológico, PCR-RFLP, proteínas inseticidas vegetativas, toxicidade.

\section{Identification and characterization of coleoptera-specific vip and cry genes in Bacillus thuringiensis isolates}

\begin{abstract}
The objective of this work was to identify and characterize cry3, vip1, vip2 and vip1/vip2 genes in a collection of 1,078 Bacillus thuringiensis isolates potentially toxic against Coleoptera larvae. Pairs of primers derived from conserved regions of genes and from sequence alignment consensus were used. Subsequently, positive isolates were characterized by PCR-RFLP, using specific restriction enzymes to identify new subclasses of genes in the isolates. One hundred and fifty-one isolates were positive for the evaluated genes, with higher frequency for the vip1/vip2 gene (139 isolates). By PCR-RFLP, 14 polymorphic profiles were observed, indicating the presence of different alleles, and, therefore, of distinct subclasses of these genes.

Index terms: bioprospection, Coleoptera, biological control, PCR-RFLP, vegetative insecticidal proteins, toxicity.
\end{abstract}

\section{Introdução}

Bacillus thuringiensis Berliner é uma bactéria Gram-positiva, comumente encontrada em solos, que vem sendo utilizada como inseticida biológico há algumas décadas. Sua toxicidade é atribuída a inclusões proteicas sintetizadas durante o processo de esporulação, quando a bactéria encontra-se sob condições adversas. As inclusões proteicas são formadas por polipeptídeos denominados de proteínas Cry, que se acumulam na periferia dos esporos na forma de cristais e se tornam tóxicos após a ingestão por larvas de insetos suscetíveis. Sua especificidade é determinada pela ligação a receptores específicos presentes no epitélio do intestino médio dos insetos-alvo (Fiuza, 2010).

Alguns isolados de $B$. thuringiensis são capazes de sintetizar outras proteínas tóxicas durante a fase de crescimento vegetativo, as quais não formam cristais e não têm homologia com as proteínas Cry. Essas toxinas são denominadas de proteínas inseticidas vegetativas ("vegetative insecticidal protein" - Vip) (Estruch et al., 1996), dentre as quais, as proteínas Vip1 e Vip2 formam uma toxina binária que apresenta atividade contra larvas de coleópteros (Leuber et al., 2006; Hernández-Rodríguez et al., 2009).

Pesq. agropec. bras., Brasília, v.46, n.9, p.1053-1060, set. 2011 
Diversas pesquisas vêm sendo realizadas para identificar novas proteínas de $B$. thuringiensis com atividade tóxica contra pragas que não são suscetíveis às toxinas conhecidas (Sauka et al., 2006; Hernández-Rodríguez et al., 2009; Costa et al., 2010). Além disso, a resistência a algumas toxinas de $B$. thuringiensis tem sido observada em certas populações de insetos, o que torna importante a busca de novas classes de proteínas inseticidas para programas de manejo da resistência (Hernández-Rodríguez et al., 2009).

Há relatos na literatura de que as proteínas Vip ligam-se em diferentes sítios nas células do epitélio intestinal de insetos-alvo, quando comparadas às proteínas Cry, o que as torna excelentes candidatas para a utilização conjunta, podendo ser aplicadas para ampliar o espectro de toxicidade e minimizar o risco de resistência cruzada em organismos geneticamente modificados (Beard et al., 2008; Hernández-Rodríguez et al., 2009).

Neste contexto, o estudo da variabilidade genética de diferentes isolados de $B$. thuringiensis e a busca de novas classes e subclasses de proteínas inseticidas têm sido realizados principalmente com auxílio da técnica de reação em cadeia da polimerase (PCR), para identificar a presença de genes desconhecidos e direcionar os bioensaios de toxicidade (Bravo et al., 1998; Sauka et al., 2006; Hernández-Rodríguez et al., 2009).

A PCR também tem sido utilizada em combinação com a técnica de polimorfismo de comprimento dos fragmentos de restrição (RFLP), na qual o produto de amplificação é clivado com enzimas de restrição e o padrão de bandas obtido em géis determina os tipos de genes cry e vip presentes nos isolados bacterianos, dentro de uma mesma classe, o que também pode indicar a presença de novos genes (diferentes alelos) (Sauka et al., 2006; Liu et al., 2009).

O objetivo deste trabalho foi identificar e caracterizar os genes cry3, vip1, vip2 e vip1/vip2, por meio da técnica de PCR, em uma coleção de 1.078 isolados de $B$. thuringiensis potencialmente tóxicos para larvas de coleópteros.

\section{Material e Métodos}

Foram utilizados 1.078 isolados de $B$. thuringiensis pertencentes à coleção do Laboratório de Genética de Bactérias, da Faculdade de Ciências Agrárias e Veterinárias, da Universidade Estadual Paulista, Jaboticabal, SP.

O DNA dos isolados foi extraído conforme a metodologia descrita por Letowski et al. (2005). $\mathrm{O}$ isolado $B$. thuringiensis var. tenebrionis (coleóptero-específico) foi utilizado como controle positivo nas amplificações, para todos os genes avaliados.

A técnica de PCR foi utilizada para identificar os genes cry3, vip1, vip2 e vip1/vip2 no DNA dos isolados de $B$. thuringiensis. Para isso, foram utilizados os seguintes pares de oligonucleotídeos iniciadores obtidos a partir de regiões conservadas dos genes e do alinhamento de sequências consenso: Gral-Cry3 (Ben-Dov et al., 1997), Gral-Vip1 e Gral-Vip2 (oligonucleotídeos degenerados) (Hernández-Rodríguez et al., 2009). A região intergênica dos genes vip 1 e vip 2 foi analisada, tendose utilizado o par de iniciadores Gral-Vip1/Vip2 (Shi et al., 2007) (Tabela 1).

As reações de amplificação para os respectivos pares de iniciadores foram conduzidas em volume total de $20 \mu \mathrm{L}$, constituído por: $20 \mathrm{ng}$ de DNA molde; 2,5 mmol L-1 da solução de dNTP; $2 \mathrm{mmol} \mathrm{L}^{-1}$ de $\mathrm{MgCl}_{2} ; 0,2 \mu \mathrm{mol} \mathrm{L}^{-1}$ de cada iniciador; $1 \mathrm{U}$ da enzima Taq DNA polimerase (Invitrogen, Carlsbad, CA, EUA); solução tampão - Tris $200 \mathrm{mmol} \mathrm{L}^{-1}$; $500 \mathrm{mmol} \mathrm{L}^{-1}$ de $\mathrm{KCl}$, pH 8,4 para reação de PCR (10X); e água destilada grau Milli-Q previamente esterilizada (qsp $20 \mu \mathrm{L}$ ). A amplificação foi processada em aparelho termociclador (MJ Research, Inc., Watertown, MA, EUA), conforme as seguintes condições: para o par de iniciadores Gral-Cry3, 5 min a $94^{\circ} \mathrm{C}$, 30 ciclos de $1 \mathrm{~min}$ a $94^{\circ} \mathrm{C}, 1 \mathrm{~min}$ a $52^{\circ} \mathrm{C}, 1 \mathrm{~min}$ a $72^{\circ} \mathrm{C}$, com extensão final de 5 min a $72^{\circ} \mathrm{C}$; para os pares de iniciadores Gral-Vip1 e Gral-Vip2, 5 min a $95^{\circ} \mathrm{C}, 35$ ciclos de $1 \mathrm{~min}$ a $95^{\circ} \mathrm{C}, 1 \mathrm{~min}$ a $47^{\circ} \mathrm{C}, 1,5 \mathrm{~min}$ a $72^{\circ} \mathrm{C}$, com extensão final de $10 \mathrm{~min}$ a $72^{\circ} \mathrm{C}$; e, para o par de iniciadores Gral-Vip1/Vip2, 5 min a $94^{\circ} \mathrm{C}$, 30 ciclos de $1 \min$ a $94^{\circ} \mathrm{C}, 1 \min$ a $48^{\circ} \mathrm{C}, 1 \min$ a $72^{\circ} \mathrm{C}$, com extensão final de $10 \mathrm{~min}$ a $72^{\circ} \mathrm{C}$.

Após a realização das amplificações, foi adicionado $3 \mu \mathrm{L}$ de tampão de amostra ("loading buffer" - 0,5\% de azul de bromofenol em glicerol a 50\%) em cada amostra amplificada. O volume final de $10 \mu \mathrm{L}$ foi aplicado em gel de agarose a $1,5 \%$, contendo brometo de etídio $\left(0,5 \mu \mathrm{g} \mathrm{mL}^{-1}\right)$ e, posteriormente, submetido à eletroforese horizontal em cuba Sunrise por 2 horas 
a $100 \mathrm{~V}$, em tampão TBE $1 \mathrm{X}$ (Tris $89 \mathrm{mmol} \mathrm{L}^{-1}$, EDTA 2,5 $\mathrm{mmol} \mathrm{L}^{-1}$ e $89 \mathrm{mmol} \mathrm{L}^{-1}$ de ácido bórico, com

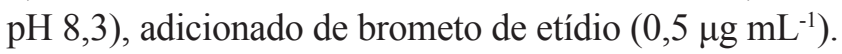
Em todas as eletroforeses realizadas, utilizou-se uma amostra de DNA com fragmentos de tamanhos conhecidos, múltiplos de $1 \mathrm{~kb}$ ("1kb DNA ladder") (Invitrogen, Carlsbad, CA, EUA), a qual serviu como referência para verificação dos tamanhos dos fragmentos obtidos nas reações de amplificação. Em seguida, os géis de agarose foram visualizados sob luz ultravioleta (UV) e fotodocumentados em Gel Doc 2000 (Bio-Rad, Hercules, CA, EUA), com uso do programa Quantity-one (Bio-Rad, Hercules, CA, EUA).

Após a amplificação dos genes cry3, vip1, vip2 e vip1/vip2, procurou-se detectar possíveis polimorfismos nessa região por meio da técnica de PCR-RFLP, para identificar novas subclasses de genes nos isolados. Para tanto, a escolha das enzimas de restrição foi feita com uso do programa pDRAW 32 AcacloneSoftware, (Acaclone, Koge, Sjaelland, Dinamarca), o qual forneceu a localização dos iniciadores gerais, as enzimas de restrição e os seus respectivos sítios, dentro da região amplificada dos genes. Assim, foram identificadas as enzimas de restrição, a quantidade de fragmentos gerados e seus respectivos tamanhos.

As enzimas específicas EcoRI, HincII e HpaII para o gene cry3 (14 isolados); AluI e MboI para o gene vip1 (134 isolados); HpaII e BsaAI para o gene vip2 (62 isolados); e BSaAI e Sau96I para o gene vip1/vip2 (139 isolados) foram utilizadas, separadamente, para verificar diferenças entre sítios de restrição e identificar novos alelos dentro das famílias gênicas analisadas.

As reações de restrição foram conduzidas no volume total de $10 \mu \mathrm{L}$ - com $5 \mu \mathrm{L}$ de água, $1 \mathrm{U}$ da enzima, $1 \mu \mathrm{L}$ de tampão (10X) Kit da enzima (Uniscience, Ipswich,
MA, EUA) e $3 \mu \mathrm{L}$ do produto de DNA amplificado - e foram mantidas a $37^{\circ} \mathrm{C}$ por $120 \mathrm{~min}$. Após a realização das restrições, um volume de $10 \mu \mathrm{L}$ de cada amostra, acrescido de $3 \mu \mathrm{L}$ de tampão de "loading buffer", foi aplicado em gel de agarose a $1,5 \%$, contendo brometo de etídio $\left(0,5 \mu \mathrm{g} \mathrm{mL}^{-1}\right)$ e, em seguida, foi submetido à eletroforese horizontal em cuba Sunrise por 2 horas a $100 \mathrm{~V}$, em tampão TBE $1 \mathrm{X}$, adicionado de brometo de etídio $\left(0,5 \mu \mathrm{g} \mathrm{mL} \mathrm{m}^{-1}\right)$. Utilizou-se uma amostra de DNA com fragmentos de tamanhos conhecidos, múltiplos de 1 kb ("1 kb DNA ladder") (Invitrogen, Carlsbad, CA, EUA), a qual foi utilizada para verificação dos tamanhos dos fragmentos obtidos nas reações de restrição, além de uma amostra do produto amplificado, não restringido, obtido para a linhagem $B$. thuringiensis var. tenebrionis.

Em seguida, os géis de agarose foram visualizados sob luz ultravioleta (UV) e fotodocumentados em Gel Doc 2000 (Bio-Rad, Hercules, CA, EUA), por meio do programa Quantity-one (Bio-Rad, Hercules, CA, EUA).

A combinação de cada produto amplificado de PCR, com presença ou ausência de sítio de restrição para cada enzima, foi utilizada para definir a existência de alelos para um loco particular. A análise de haplótipos por esse método foi representada pela combinação de alelos (amplificação + restrição) para cada um dos locos (Picchi et al., 2006; Fatoretto et al., 2007).

Para a análise estatística, foi criada uma matriz de amplificação + restrição. Os dados foram agrupados e submetidos à análise de variância molecular (AMOVA), com uso do programa Arlequin (Schneider et al., 2000). A diversidade genética dos isolados, quanto aos genes avaliados, foi estimada e a estrutura de grupos foi analisada.

Tabela 1. Iniciadores utilizados para amplificação dos genes cry3, vip1, vip2 e vip1/vip2 de isolados de Bacillus thuringiensis e tamanho dos produtos amplificados.

\begin{tabular}{|c|c|c|c|}
\hline Iniciador & Sequência & Nucleotídeo & Tamanho (pb) \\
\hline \multirow[t]{2}{*}{ Gral-Cry3 $3^{(1)}$} & Direta & 5'CGTTATCGCAGAGAGATGACATTAAC3' & 620 \\
\hline & Reversa & 5'CATCTGTTGTTTCTGGAGGCAAT3' & \\
\hline \multirow[t]{2}{*}{ Gral-Vip $1^{(2)}$} & Direta & 5’TTATTAGATAAACAACAACAAGAATATCAATCTATTMGNTGGATHGG3' & 585 \\
\hline & Reversa & 5'GATCTATATCTCTAGCTGCTTTTTCATAATCTSARTANGGRTC3' & \\
\hline \multirow[t]{2}{*}{ Gral-Vip2 $2^{(2)}$} & Direta & 5'GATAAAGAAAAAGCAAAAGAATGGGRNAARRA3' & 845 \\
\hline & Reversa & 5'CCACACCATCTATATACAGTAATATTTTCTGGDATNGG3' & \\
\hline \multirow[t]{2}{*}{ Gral-Vip1/Vip2 $2^{(3)}$} & Direta & 5'AAATTAGTGATCCGTTACCTTCTT3' & 742 \\
\hline & Reversa & 5'CAACTTGCTTTTCTTTCCCTTTAT3' & \\
\hline
\end{tabular}

${ }^{(1)}$ Ben-Dov et al. (1997). ${ }^{(2)}$ Hernández-Rodríguez et al. (2009). ${ }^{(3)}$ Shi et al. (2007). 
A análise de agrupamento por método hierárquico foi utilizada para classificar os genes vip em grupos, para maximizar a similaridade interna entre eles, bem como a heterogeneidade, com base nas informações da PCR-RFLP. As análises foram realizadas com o programa Statistica, versão 7.0 (Statsoft, 2004), tendose considerado a distância euclidiana como medida de semelhança e o método de Ward (Hair et al., 2005) como método de ligação entre os grupos.

\section{Resultados e Discussão}

O DNA dos 1.078 isolados de B. thuringiensis amplificados por PCR apresentaram diferentes tamanhos de produtos. Para o gene cry3, o tamanho dos produtos da amplificação foi de $620 \mathrm{pb}$. Com relação aos genes vip1, vip2 e vip1/vip2 os tamanhos foram de 585, 845 e $742 \mathrm{pb}$, respectivamente (Tabela 1 e Figura 1).
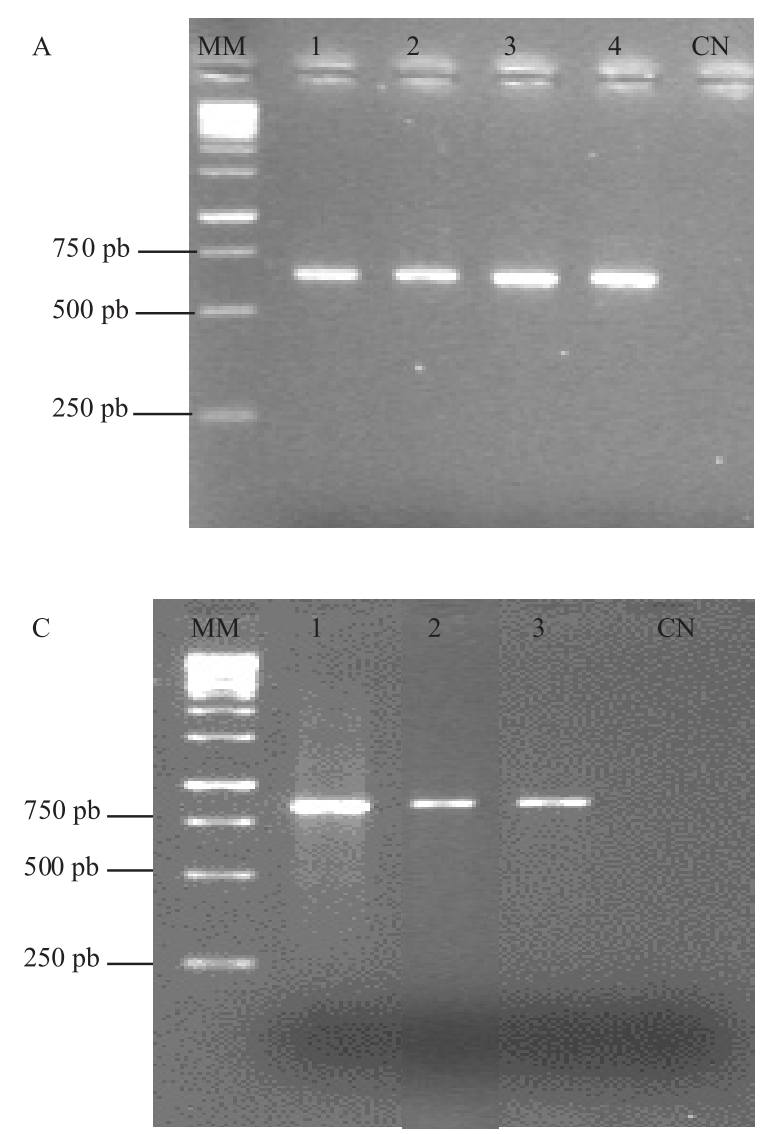

Figura 1. Perfil eletroforético de fragmentos amplificados de DNA de isolados de Bacillus thuringiensis. A, iniciador Gral-Cry3 (620 pb); B, iniciador Gral-Vip1 (585 pb); C, iniciador Gral-Vip2 (845 pb); D, iniciador Gral-Vip1/Vip2 (742 pb). MM, 1 kb DNA ladder; 1, Bacillus thuringiensis var. tenebrionis; CN, controle negativo da reação.
Dos 1.078 isolados, 14 isolados $(1,29 \%)$ apresentaram um produto de amplificação esperado para o gene cry3. Quanto ao gene vip, 134 isolados $(12,43 \%)$ apresentaram produto de amplificação correspondente ao gene vipl e 62 isolados $(5,75 \%)$ ao gene vip2. Cento e trinta e nove isolados $(12,89 \%)$ apresentaram produto de amplificação correspondente ao gene vip1/vip2, o que indica maior frequência deste gene na coleção analisada. Nenhum isolado apresentou amplificação para os quatro genes simultaneamente.

Hernández-Rodríguez et al. (2009) obtiveram resultados semelhantes quanto à frequência dos genes vip1 e vip2. Ao analisar 507 linhagens, estes autores obtiveram $10,7 \%$ de isolados amplificados para o gene vip1 e 9,1\% para o gene vip2. Diferentemente, Arrieta et al. (2004), ao avaliar uma coleção de isolados de observaram elevada frequência de genes vip2. Arrieta \& Espinoza (2006) também obtiveram resultados

B
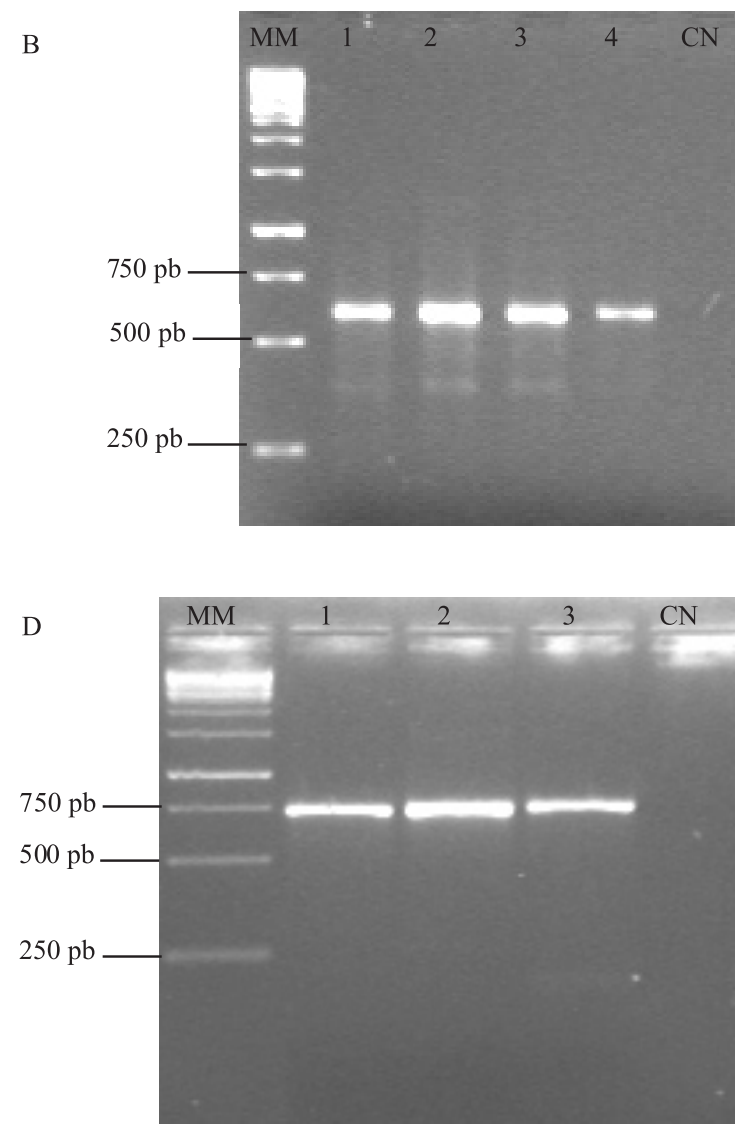
B. thuringiensis de plantações de café na Costa Rica, 
contrastantes, ao avaliar 146 isolados, com apenas um isolado positivo para o gene vip2 e ausência do gene vip1 na coleção analisada.

Para o gene vip1/vip2, Warren et al. (1996) obtiveram distribuição de $11,9 \%$ entre os isolados avaliados, semelhantemente ao percentual encontrado no presente trabalho. Já Espinasse et al. (2003), ao analisar 125 isolados de $B$. thuringiensis, identificaram os genes vip1/vip 2 em $34,4 \%$ dos isolados estudados, percentual superior ao obtido no presente trabalho.

Apenas 1,29\% dos isolados foram positivos para o gene cry3, o que diferiu de Bravo et al. (1998), Pinto \& Fiuza (2008) e Nazarian et al. (2009), que relataram maior presença de genes cry 3 nos isolados testados, com $12,5,21,70$ e $22,34 \%$, respectivamente. Ben-Dov et al. (1997), no entanto, não identificaram esse gene nos isolados avaliados.

As diferenças encontradas entre os trabalhos analisados e os resultados obtidos no presente trabalho evidenciam a ampla distribuição de $B$. thuringiensis em diferentes habitats, além de sua elevada diversidade genética. Entretanto, na maioria das coleções avaliadas, não foi constatada alta frequência de genes coleóptero-específicos. Azambuja et al. (2009) associaram a presença de determinada família gênica, em diferentes coleções, ao local de origem de B. thuringiensis. A distribuição de genes na coleção analisada por Pinto \& Fiuza (2003), em comparação a outras regiões geográficas, indicou diferenças que também podem estar associadas a fatores abióticos, como características físico-químicas do solo, as quais não foram avaliadas no presente trabalho.

Em relação aos isolados que não amplificaram para os genes avaliados, é importante ressaltar que as sequências oligonucleotídicas iniciadoras utilizadas foram desenhadas a partir de sequências consenso, por meio do alinhamento de poucas subclasses de genes coleóptero-específicos descritas na literatura. Assim, presume-se a existência de subclasses de genes que ainda não foram caracterizadas ou relatadas na literatura, o que explicaria porque as sequências oligonucleotídicas iniciadoras utilizadas não amplificaram para os genes cry3, vip1, vip2 e vip1/vip2 no presente trabalho.

A identificação de genes vip e cry em coleções de B. thuringiensis é extremamente importante, pois permite a seleção de isolados específicos, potencialmente tóxicos para determinadas ordens de insetos, para utilização em bioensaios de toxicidade.
As análises realizadas quanto à diversidade de proteínas toxinas nos isolados avaliados indicam o seu grande potencial para o controle de diferentes espécies de pragas de importância econômica, com destaque para aquelas da ordem Coleoptera.

Diversos trabalhos relatam a ocorrência de genes vip e cry em isolados de B. thuringiensis, determinada apenas por PCR (Loguercio et al., 2002; Espinasse et al., 2003; Arrieta \& Espinoza, 2006; Nazarian et al., 2009; Baig \& Mehnaz, 2010). Embora seja uma técnica importante para avaliar a composição gênica de coleções de $B$. thuringiensis e para prever toxicidade (Thuler et al., 2007; Costa et al., 2010), a PCR permite apenas a identificação da classe do gene amplificado e não da subclasse a qual o gene em estudo pertence. Portanto, a técnica de PCR-RFLP vem sendo utilizada para auxiliar na detecção e na caracterização de diferentes subclasses de genes cry e vip (Beard et al., 2008; Liu et al., 2009; Hernández-Rodríguez et al., 2009). Contudo, essa técnica não permite diferenciar genes intimamente relacionados, com perfis semelhantes (Hernández-Rodríguez et al., 2009).

Por meio da técnica de PCR-RFLP foi possível identificar polimorfismo em todos os genes analisados, o que indica a presença de diferentes alelos para os respectivos genes. Em relação ao gene cry3 e vipl, três padrões polimórficos foram obtidos após as análises da restrição. Para os genes vip2 e vip1/vip2 foram obtidos dois perfis polimórficos. Esses resultados

Tabela 2. Frequência, desvio-padrão e distribuição de haplótipos de Bacillus thuringiensis para os genes cry3 e vip.

\begin{tabular}{|c|c|c|c|}
\hline $\begin{array}{l}\text { № de } \\
\text { haplótipos }\end{array}$ & $\begin{array}{c}\text { Frequência } \\
(\%)\end{array}$ & Desvio-padrão & Haplótipo \\
\hline \multicolumn{4}{|c|}{ Gene cry3 } \\
\hline 1 & 0,2000 & 0,1069 & 1111 \\
\hline 2 & 0,2000 & 0,1069 & 1222 \\
\hline 3 & 0,6000 & 0,1309 & 1233 \\
\hline \multicolumn{4}{|c|}{ Gene vip } \\
\hline 1 & 0,0071 & 0,0071 & 111111111 \\
\hline 2 & 0,4643 & 0,0423 & 111122000 \\
\hline 3 & 0,0357 & 0,0157 & 111000000 \\
\hline 4 & 0,0071 & 0,0071 & 111132000 \\
\hline 5 & 0,4000 & 0,0416 & 111122121 \\
\hline 6 & 0,0071 & 0,0071 & 122122121 \\
\hline 7 & 0,0143 & 0,0101 & 122122000 \\
\hline 8 & 0,0214 & 0,0123 & 122142000 \\
\hline 9 & 0,0071 & 0,0071 & 111142000 \\
\hline 10 & 0,0143 & 0,0101 & 111122120 \\
\hline 11 & 0,0214 & 0,0123 & 122143122 \\
\hline
\end{tabular}


são indicativos de conservação significativa nas sequências dos produtos amplificados, evidenciada pela identificação de apenas três alelos para as enzimas que obtiveram maior número de sítios de restrição. Entretanto, a variabilidade genética observada pode indicar a possibilidade da existência de mais de uma subclasse de gene cry3, vip1 ou vip2 nos isolados avaliados.

A análise da estrutura genética por meio do programa Arlequin permitiu a caracterização haplotípica dos isolados de B. thuringiensis da coleção (Tabela 2). Entre os 151 isolados avaliados, foram verificados 14 haplótipos: três correspondentes ao gene cry3 e 11 ao gene vip (vip1, vip2 e vip1/vip2). Em relação aos haplótipos obtidos para o gene cry3, a frequência do haplótipo 3 foi de $0,6 \%$ dentro da coleção avaliada. Para os haplótipos 1 e 2, a frequência observada foi de $0,2 \%$ cada um. Para os genes vip analisados, obtevese frequência de $0,4 \%$ para os isolados agrupados nos haplótipos 2 e 5 , o que indica sua elevada frequência na coleção. Os isolados restantes distribuíram-se em nove haplótipos, com frequência inferior.

A partir dos perfis polimórficos dos genes vip1, vip2 e vip1/vip2, por análise de agrupamento por método hierárquico, constatou-se a formação de dois grupos de isolados ( $\mathrm{G} 1$ e $\mathrm{G} 2$ ), que foram subdivididos em dois grupos cada um: G1_1, G1_2, G2_1 e G2_2. O grupo G1 foi subdivido nos subgrupos G1_1 (isolados I_1 e I_3) e G1_2 (isolados I_27, I_28, I_125 e I_135). O grupo G2 foi subdivido nos subgrupos G2_1 (isolados I_2 e I_4) e G2_2 (isolados I_32, I_33 e I_36). Os isolados pertencentes ao mesmo agrupamento apresentaram padrões de amplificação + restrição semelhantes, o que indica a variabilidade genética entre os grupos formados. A análise multivariada de agrupamento contribui para a caracterização gênica de isolados de B. thuringiensis e deve ser utilizada na fase exploratória na busca e na identificação de proteínas inseticidas de bactérias entomopatogênicas.

Diversos estudos de análise de diversidade genética de bactérias vêm sendo realizados nos últimos anos. Costa et al. (2010), ao avaliar a estrutura de grupos de 45 isolados de uma coleção, identificaram 21 haplótipos em relação aos genes cry e cyt, dos quais 13 haplótipos são exclusivos dos isolados pertencentes à coleção do Laboratório de Genética de Bactérias, da Universidade Estadual Paulista, Jaboticabal, SP. Thuler et al. (2007), ao analisar a estrutura genética de 650 isolados de B. thuringiensis de diferentes regiões brasileiras, com base em resultados de amplificação e restrição, obtiveram 78 haplótipos para diferentes subclasses do gene cryl, definidos para as populações.

Cabe destacar que, entre os 151 isolados amplificados para os genes cry e vip, foi observada maior frequência de isolados com origem em Minas Gerais (35,48\%), seguido de Goiás (30,96\%), São Paulo (7,09\%) e Paraná (0,64\%). Cerca de $23,87 \%$ dos isolados amplificados são de regiões geográficas não identificadas. Com base nos estudos de distribuição de $B$. thuringiensis em diferentes ecossistemas (Pinto \& Fiuza, 2003; Azambuja et al., 2009), foi observada variabilidade regional para os genes cry entre os isolados analisados.

As análises de agrupamento haplotípica para os genes vip permitiram identificar dois importantes grupos que apresentaram maior frequência (haplótipos 2 e 5) e se distribuem entre Minas Gerais e Goiás, respectivamente, consideradas importantes regiões agrícolas e alvo de inúmeros insetos-praga, inclusive da ordem Coleoptera.

Embora ainda escassos, estudos de coevolução de isolados de $B$. thuringiensis e seus hospedeiros suscetíveis (insetos-alvo) têm sido propostos. A prospecção de isolados de $B$. thuringiensis, associada às características do habitat e à sua diversidade genética, consiste em estratégia importante para a identificação de novas proteínas Cry e Vip, com diferentes especificidades (Arrieta \& Espinoza, 2006). Portanto, a presença de $B$. thuringiensis em diferentes ecossistemas pode estar relacionada aos fatores bióticos e abióticos presentes no hábitat (Pinto \& Fiuza, 2003; Arrieta \& Espinoza, 2006; Azambuja et al., 2009). Consequentemente, análises de toxicidade em larvas de insetos da ordem Coleoptera constituem importante ferramenta para corroborar a possível correlação existente entre origem dos isolados, sua coevolução e a presença de polimorfismos gênicos em coleções de B. thuringiensis.

\section{Conclusões}

1. Há diferentes subclasses de genes cry e vip coleóptero-específicos na coleção de isolados de Bacillus thuringiensis. 
2. A técnica de PCR-RFLP permite a identificação de haplótipos para os genes cry3 e vip na coleção de B. thuringiensis.

3. Há maior frequência do gene vip1/vip2 (região adjacente) na coleção analisada, em comparação aos outros genes em estudo.

\section{Referências}

ARRIETA, G.; ESPINOZA, A.M. Characterization of a Bacillus thuringiensis strain collection isolated from diverse Costa Rican natural ecosystems. Revista de Biología Tropical, v.54, p.13-27, 2006.

ARRIETA, G.; HERNÁNDEZ, A.; ESPINOZA, A.M. Diversity of Bacillus thuringiensis strains isolated from coffee plantations infested with the coffee berry borer Hypothenemus hampei Ferrari. Revista de Biología Tropical, v.52, p.757-764, 2004.

AZAMBUJA, A.O. de; ALLES, G.C.; FRITZ, L.L.; RECHE, M.H.R.; FIUZA, L.M. Ecologia de Bacillus entomopatogênicos. Biotecnologia Ciência e Desenvolvimento, v.38, p.14-23, 2009.

BAIG, D.N.; MEHNAZ, S. Determination and distribution of cry-type genes in halophilc Bacillus thuringiensis isolates of Arabian Sea sedimentary rocks. Microbiological Research, v.165, p.376-383, 2010 .

BEARD, C.E.; COURT, L.; BOETS, A.; MOURANT, R.; VAN RIE, J.; AKHURST, R.J. Unusually high frequency of genes encoding vegetative insecticidal proteins in an Australian Bacillus thuringiensis collection. Current Microbiology, v.57, p.195-199, 2008.

BEN-DOV, E.; ZARITSKY, A.; DAHAN, E.; BARAK, Z.; SINAI, R.; MANASHEROB, R.; KHAMRAEV, A.; TROITSKAYA, E.; DUBITSKY, A.; BEREZINA, N.; MARGALITH, Y. Extended screening by PCR for seven cry-group genes from field-collected strains of Bacillus thuringiensis. Applied and Environmental Microbiology, v.63, p.4883-4890, 1997.

BRAVO, A.; SARABIA, S.; LOPEZ, L.; ONTIVEROS, H.; ABARCA, C.; ORTIZ, A.; ORTIZ, M.; LINA, L.; VILLALOBOS, F.J.; PEÑA, G.; NUÑEZ-VALDEZ, M.; SOBERÓN, M.; QUINTERO, R. Characterization of cry genes in a Mexican Bacillus thuringiensis strain collection. Applied and Environmental Microbiology, v.64, p.4965-4972, 1998.

COSTA, J.R.V. da; ROSSI, J.R.; MARUCCI, S.C.; ALVES, E.C. da C.; VOLPE, H.X.L.; FERRAUDO, A.S.; LEMOS, M.V.F.; DESIDÉRIO, J.A. Atividade tóxica de isolados de Bacillus thuringiensis a larvas de Aedes aegypti (L.) (Diptera: Culicidae). Neotropical Entomology, v.39, p.757-766, 2010.

ESPINASSE, S.; CHAUFAUX, J.; BUISSON, C.; PERCHAT, S.; GOHAR, M.; BOURGUET, D.; SANCHIS, V. Occurrence and linkage between secreted insecticidal toxins in natural isolates of Bacillus thuringiensis. Current Microbiology, v.47, p.501-507, 2003.

ESTRUCH, J.J.; WARREN, G.W.; MULLINS, M.A.; NYE, G.J.; CRAIG, J.A.; KOZIEL, M.G. Vip3A, a novel Bacillus thuringiensis vegetative insecticidal protein with a wide spectrum of activities against lepidopteran insects. Proceedings of the National Academy of Sciences of the United States of America, v.93, p.5389-5394, 1996.

FATORETTO, J.C.; SENA, J.A.D.; BARRETO, M.R.; LEMOS, M.V.F.; BOIÇA JÚNIOR, A.L. Associação de bioensaios e caracterização molecular para seleção de novos isolados de Bacillus thuringiensis efetivos contra Spodoptera frugiperda (J.E. Smith) (Lepidoptera: Noctuidae). Biological Control, v.36, p.737-745, 2007.

FIUZA, L.M. Mecanismo de ação de Bacillus thuringiensis. Biotecnologia Ciência e Desenvolvimento, v.38, p.32-35, 2010.

HAIR, J.F.; ANDERSON, R.E.; TATHAM, R.L.; BLACK, W. Análise multivariada de dados. 5.ed. Porto Alegre: Bookman, 2007. 593p.

HERNÁNDEZ-RODRÍGUEZ, C.S.; BOETS, A.; VAN RIE, J.; FERRÉ, J. Screening and identification of vip genes in Bacillus thuringiensis strains. Journal of Applied Microbiology, v.107, p.219-225, 2009.

LETOWSKI, J.; BRAVO, A.; BROUSSEAU, R.; MASSON, L. Assessment of cryl gene contents of Bacillus thuringiensis strains by use of DNA microarrays. Applied and Environmental Microbiology, v.71, p.5391-5398, 2005.

LEUBER, M.; ORLIK, F.; SCHIFFLER, B.; SICKMANN, A.; BENZ, R. Vegetative insecticidal protein (Vip1Ac) of Bacillus thuringiensis HD201: evidence for oligomer and channel formation. Biochemistry, v.45, p.283-288, 2006.

LIU, T.; GUO, W.; SUN, W.; SUN, Y. Biological characteristics of Bacillus thuringiensis strain Bt11 and identification of its cry-type genes. Frontiers of Agriculture in China, v.3, p.159-163, 2009.

LOGUERCIO, L.L.; BARRETO, M.L.; ROCHA, T.L.; SANTOS, C.G.; TEIXEIRA, F.F.; PAIVA, E. Combined analysis of supernatant-based feeding bioassays and PCR as a first-tier screening strategy for Vip-derived activities in Bacillus thuringiensis strains effective against tropical fall armyworm. Journal of Applied Microbiology, v.93, p.269-277, 2002.

NAZARIAN, A.; JAHANGIRI, R.; JOUZANI, G.S.; SEIFINEJAD, A.; SOHEILIVAND, S.; BAGHERI, O.; KESHAVARZI, M.; ALAMISAEID, K. Coleopteran-specific and putative novel cry genes in Iranian native Bacillus thuringiensis collection. Journal of Invertebrate Pathology, v.102, p.101-109, 2009.

PICCHI, S.C.; VILAS-BOAS, L.A.; CERESINI, P.C.; LEMOS, E.G.M.; LEMOS, M.V.F. Strain variability in the DNA immigration control region (ICR) of Xylella fastidiosa. Research in Microbiology, v.157, p.254-262, 2006.

PINTO, L.M.N.; FIUZA, L.M. Distribuição de genes cry de Bacillus thuringiensis isolados de solos do Estado do Rio Grande do Sul, Brasil. Ciência Rural, v.33, p.699-702, 2003.

PINTO, L.M.N.; FIUZA, L.M. Genes cry de Bacillus thuringiensis aplicados na engenharia genética de plantas, conferindo resistência a insetos-praga. Neotropical Biology and Conservation, v.3, p.159-168, 2008. 
SAUKA, D.H.; COZZI, J.G.; BENINTENDE, G.B. Detection and identification of cry1I genes in Bacillus thuringiensis using polymerase chain reaction and restriction fragment length polymorphism analysis. Current Microbiology, v.52, p.60-63, 2006.

SCHNEIDER, S.; ROESSLI, D.; EXCOFFIER, L. Arlequin: a software for population genetics data analysis: user manual. Version 2.0. Geneva: University of Geneva, 2000.

SHI, Y.; MA, W.; YUAN, M.; SUN, F.; PANG, Y. Cloning of vip 1/ vip2 genes and expression of Vip1Ca/Vip2Ac proteins in Bacillus thuringiensis. World Journal of Microbiology Biotechnology, v.23, p.501-507, 2007.
STATSOFT. Statistica: data analysis software system. Version 7. Tulsa: StatSoft, 2004. Available at: <www.statsoft.com>. Accessed on: 27 Oct. 2011.

THUlER, A.M.G.; THULER, R.T.; CICERO, E.A.S.; DE BORTOLI, S.A.; LEMOS, M.V.F. Estudo da variabilidade gênica em isolados brasileiros de Bacillus thuringiensis para emprego no controle biológico de Plutella xylostella. Boletín de Sanidad Vegetal, v.33, p.409-417, 2007.

WARREN, G.W. Vegetative insecticidal proteins: novel proteins for control of corn pests. In: CAROZZI, N.; KOZIEL, M. (Ed.). Advances in insect control: the role of transgenic plants. London: Taylor and Francis, 1996. p.109-121.

Recebido em 14 de janeiro de 2011 e aprovado em 5 de setembro de 2011 